\title{
Is benzoyl peroxide detectable under physiological conditions in orthopaedic cement?
}

\section{Oliver Steiner}

Institute of Chemistry,

Analytical Chemistry for Health and Environment,

University of Graz,

8010, Graz, Austria

Email: oliver.steiner.unigraz@gmail.com

\section{Komaz Melanie}

Department of Orthopedic Surgery,

Medical University of Graz,

Auenbruggerplatz 5, 8036 Graz, Austria

Email: Melanie.Komaz@ooeg.at

\section{Goessler Walter}

Institute of Chemistry

Analytical Chemistry for Health and Environment,

University of Graz, Austria

Email: walter.goessler@uni-graz.at

\section{Thomas Peter}

Department of Dermatology and Allergology, Ludwig-Maximilians-University (LMU),

Munich, 80337, Germany

Email: Peter.Thomas@med.uni-muenchen.de

\section{Kühn Klaus-Dieter*}

Department of Orthopedics and Trauma,

Medical University of Graz,

Auenbruggerplatz 5, 8036 Graz, Austria

Fax: +43 31638559517047

Email: klaus-dieter.kuehn@medunigraz.at

${ }^{*}$ Corresponding author

Abstract: Background: Until today, benzoyl peroxide (BPO) as a potential polymethyl methacrylate (PMMA) cement allergen is the subject of controversial discussion. Question/Purposes: Few cases have been reported in literature and ought to be seen critically. To address this issue, the present 
study aims to determine BPO and their degradation products biphenyl (BP) and benzoic acid (BA) within hardened cement as well as their elution from cement. Methods: Six ordinary cements characterised by different BPO: DmpT ratio were chosen for the study. Subsequently, cements were tested in-vitro under destructive, physiologic and non- physiologic conditions. Results: BPO was not detectable under destructive and physiological conditions. Cements with a $\mathrm{N}$, N-Dimethyl-para-toluidine (DmpT) surplus contained lower BPO, BP and BA concentrations compared to cements with BPO surplus. Conclusions: Furthermore, the ratio of DmpT:BPO had an impact on the turnover of BPO and its degradation products. Clinical Relevance: Moreover, BPO and BP elution under physiological conditions was not detectable $(<0.1 \mu \mathrm{g} / \mathrm{mL}$ in saline solution at a ratio of $1+9$ cement to saline solution), calling into question whether BPO is relevant as PMMA cement allergen.

Keywords: PMMA; polymethyl methacrylate; BPO; benzoyl peroxide; allergy; in-vitro; HPLC; high performance liquid chromate-graphic system; low grade infection, COPAL PALACOS.

Reference to this paper should be made as follows: Steiner, O., Melanie, K., Walter, G., Peter, T. and Klaus-Dieter, K. (2021) 'Is benzoyl peroxide detectable under physiological conditions in orthopaedic cement?', Int. J. Nano and Biomaterials, Vol. 10, No. 1, pp.34-49.

Biographical notes: Oliver Steiner received his BSc in the field of Analytical Chemistry from 2007 to 2011 and MSc from 2011 on. Since 2010-2020, he has been Project Collaborator in the University of Graz at the Institute of Chemistry in the Working group Analytical Chemistry for Health and Environment. His research focuses on the study design and sample preparation for chromatographic separations in environmental, pharmaceutical and human samples with a subsequent spectrophotometrically, molecular or mass selective detection.

Komaz Melanie - Medizinstudiuman der Medizinischen Universität Graz // 2008-2015 Praktisches Jahram Universitätsklinikum Graz Abteilungen Neurologie \& Unfallchirurgie und Krankenhaus der Barmherzigen Schwestern Linz an der Abteilungfür HNO // 2014-2015 Diplomarbeit "Über die Abgabe von BPO, Benzoat und Biphenyl aus PMMA Knochenzement" an der Klinikfür Orthopädie und orthopädische Chirurgie und am Institut für Hygiene, Mikrobiologie und Umweltmedizin Graz // 2015 Lehrpraxis Ordination Dr. Angelika Mauel in Bad Goisern am Hallstättersee // 2019 Ausbildungzur Allgemeinmediziner in 2018 und Facharztausbildung für Anästhesiologie und Intensivmedizin 2019 Tätigkeitals Notärztin // 2020 am SalzkammergutKlinikum Gmunden und Vöcklabruck.

Goessler Walter received his Diploma in Chemistry from 1985 to 1991. Since 1991-1997, he obtained his Dissertation in Analytical Chemistry and Habilitation for the subject Analytical Chemistry in 2003. His research focuses on the development and improvement of analytical methods. The quantification of trace elements and the identification of trace element species are key competences. The developed methods are then applied to answer questions and solve problems related to human health and the environment. In recent years, non-metal speciation with HPLC-ICPMS/MS has attracted his attention. Biotransformation of arsenic compounds plays a central role in his research. 
Thomas Peter received his $\mathrm{PhD}$ thesis in July 1987 and American medical examination (ECFMG, Basic Science and Clinical Science) in January 1986. He completes his state examination in 1985. Since January 1986 to September 1988, he has been working as an internships in radiology, gynaecology and immunology. He obtained his research fellowship (Department of Immunology, Johns-Hopkins-University, Baltimore, La Jolla Institute for Allergy and Immunology, San Diego) from October 1988 to June 1990. His specialty training includes Department of Dermatology, Ludwig-Maximilians-University Munich; board examinations: dermatology in June 1995, allergology in July 1995, environmental medicine in December 1996; problem based learning in October 1999 (Harvard Medical School). He has been Associate Professor in February 2000 and Professor in November 2006. His research focuses on Clinical Topics: Implant allergy ambulatory, general dermatology, student teaching. Scientific Topics: Mechanisms of implant allergy/inflammation including T-lymphocyte activation, cytokine production.

Kühn Klaus-Dieter received his University Professorship in Medical Microbiology in Orthopaedics in 2010. His habilitation in the field of medical microbiology with special emphasis on orthopaedics in Graz, Austria (Privatdozent PD habil. med. Dr.rer. nat.) in 2008. In 1991, Heraeus Kulzer $\mathrm{GmbH}$, Hanau, Wehrheim, Production Manager Pharma, scientific training of physicians and OR personnel handling of sterile products worldwide. Since 1988-1991, F. Hoffmann-La Roche, Basel, Quality Control Pharma, Microbiology, Polymers, Pharmacy; GMP inspections. He obtained his Diploma in Biology (microbiology); University of Marburg, Germany in 1987. $\mathrm{He}$ also obtained his Doctorate (Dr.rer. nat.) in Biology/Microbiology; University of Marburg (Hannover, Germany) in 1986. He completes his state examination (L3) Teacher training for grammar schools (biology, Sports), Philipps University Marburg in 1985.

\section{Introduction}

Polymethyl methacrylate (PMMA) bone cement is widely used in artificial joint replacement for fixation of total joint replacements. It buffers forces placed upon the joint. Moreover, it can be utilised as a carrier matrix for antibiotics and functions as a local drug-delivery system. Bone cements are a two-component system consisting of a liquid (or monomer) and a powder (or polymer) component.

The final PMMA cement is produced right in the operation theatre by mixing the components according to the manufacturer's instructions. The liquid component includes methyl methacrylate (MMA), N, N-Dimethyl-para-toluidine (DmpT) and hydroquinone (HQ). Depending on the brand, it may further contain colouring agents and/or other additives. The powder is composed of polymers and/or copolymers (PMMA and/or MMA), benzoyl peroxide (BPO) and sometimes colouring agents and antibiotics (Kühn et al., 2014).

The various ingredients of PMMA cements can potentially elicit allergic reactions that causing eczema, delayed wound or bone healing, recurrent effusion, pain or implant loosening (Carlsson et al., 1980; Deb, 2008; Goodman, 1996; Haddad et al., 1996; Rodgers et al., 1997; Hallab, 2001; Thomas et al., 2004). As a consequence, the body may respond with an inflammatory reaction that could lead to osteolysis and loss of the implant (Kubba et al., 1981; Thomas et al., 2004; Willert et al., 2005). 
Especially BPO is known to bear an allergy risk (39). The cases reports are sparse and should be regarded critically, though (Pegum and Medhurst, 1971; Jäger and Balda, 1979; Romaguera et al., 1985; Haddad, 1995; ASTM Specification F 451-476, 1978; Meel, 2004; Richter-Hintz et al., 2005; Schuh et al., 2004; Thomas et al., 2004, 2006; Wetzel and Thomas, 2004; Schuh et al., 2006; Edwards and Gardiner, 2007; Gothner et al., 2011; Wawrzynski et al., 2017).

All cements on the market contain BPO which will rapid react as initiator with the activator DmpT for radical polymerisation. They chemically interact at room temperature producing free radicals initiating polymerisation process. During the quick redox reaction in PMMA cement, BPO reacts to a benzoyloxy radical and a benzoate anion, and DmpT to a radical cation (Nussbaum et al., 2004).

The quantities of BPO within the cement powder component from different brands may vary $(0.5$ to more than $2 \%)$, which essentially impacts temperature and cement dough setting. A higher amount of BPO will harden the dough faster while the temperature increases proportionally. Lower amounts of BPO will slow down hardening with proportionally lower temperature (Kruppke, 2010). The BPO: DmpT ratio should be considered, since a BPO surplus may favours a complete turnover of DmpT, while a DmpT surplus may lead to quantitative consumption of BPO. Theoretically PMMA cements with an activator surplus can significantly lower the risk of peroxide remaining in the hardened matrix. Because of its slight solubility under physiological conditions, BPO is supposed to remain in the bone cement matrix as well. Even if small amounts are released over time, the effect on the body is regarded as non-critical. BPO is rapidly metabolised to benzoic acid (BA) and CO2 (Ege, 1993; Shintani, 1993; Kühn, 2000). The induced cell damage is reversible in the absence of the chemical agent (AMG, 2004). Analytic tests are still needed to monitor the behaviour of BPO and its degradation products in cement moulds.

The present study aims to determine the BPO content in selected cement brands. Palacos $^{\circledR} \mathrm{R}$, Copal $^{\circledR} \mathrm{G}+\mathrm{V}$ and Antibiotic Simplex ${ }^{\circledR}$ with Tobramycin were chosen representing cements containing a DmpT surplus, while Hi Fatigue ${ }^{\circledR}, \mathrm{CMW}^{\circledR} 1 \mathrm{G}$ and Cemex $^{\circledR}$ Genta represent cements with a BPO surplus. BPO elution behaviour from various cement moulds were tested under destructive, physiologic and non- physiologic conditions in-vitro.

\section{Materials/Methods}

\subsection{Cements}

Six ordinary cements were selected. According to their composition, they were subdivided into two groups: Group 1 were cements containing a DmpT surplus (Palacos ${ }^{\circledR}$ $\mathrm{R}$, Copal $^{\circledR} \mathrm{G}+\mathrm{V}$, Antibiotic Simplex ${ }^{\circledR}$ with Tobramycin). Group 2 were cements containing a BPO surplus (Hi Fatigue $\left.{ }^{\circledR}, \mathrm{CMW}^{\circledR} 1 \mathrm{G}\right) \mathrm{Cemex}^{\circledR}$ Genta. The values of BPO and DmpT content given by the manufacturers are summarised for all cements (Table 1). 
Table 1 Detailed BPO and DmpT content according to the manufacturer's indication for each cement

\begin{tabular}{lcccc}
\hline Cement & $P: L$ & BPO [\%] & DmpT & $\begin{array}{c}\text { Molar [\%] ratio } \\
\text { BPO:DmpT }\end{array}$ \\
\hline Palacos ${ }^{\circledR} \mathrm{R}$ & $2: 1$ & 0.75 & 2 & $1: 2.4$ \\
Copal ${ }^{\circledR} \mathrm{G}+\mathrm{V}$ & $2: 1$ & 0.75 & 2 & $1: 2.4$ \\
Antibiotic & $2: 1$ & 1.24 & 2.5 & $1: 1.8$ \\
Simplex ${ }^{\circledR} \mathrm{T}$ & & & & \\
Hi Fatigue & $2: 1$ & 0.84 & 0.65 & $1: 0.7$ \\
CMW ${ }^{\circledR} 1 \mathrm{G}$ & $2: 1$ & 1.95 & $\leq 1.50$ & $1: 0.7$ \\
Cemex & $2: 0.75$ & 3.00 & 1.80 & $1: 0.4$ \\
Genta & & & & \\
\hline
\end{tabular}

L: liquid; P: powder.

\subsection{Producing mouldings}

Powder was mixed with the liquid according to manufacturer specification' instructions. Curing took place in a silicon mould. PALACOS ${ }^{\circledR} \mathrm{R}$ and Hi Fatigue ${ }^{\circledR}$ (representative cements) were performed as triplicate. The other cements were prepared once.

\subsection{High performance liquid chromatography method (HLPC)}

Samples were analysed with a high performance liquid chromate-graphic system (HPLC, 1260 Series, Agilent Technologies, Germany, Waldbronn) equipped with a variable wavelength detector for UV detection (adapted from Gaddipati et al., 1983). For the separation of the investigated compounds a Zorbax SB-Phenyl narrow-bore column ( $2.1 \mathrm{x}$ $150 \mathrm{~mm}, 5 \mu \mathrm{m}$, Agilent Technologies, Germany, Waldbronn) (Romaguera et al., 1985) was used.

The column temperature was set to $40^{\circ} \mathrm{C}$. Standards of five different concentrations $(0.1,0.5,1,10$ and $100 \mu \mathrm{g} / \mathrm{mL})$ of benzoic acid, biphenyl and BPO were used for calibration prior to the analysis.

\subsection{Sample preparation}

\subsubsection{BPO content in powder components}

An aliquot ( $\sim 100 \mathrm{mg}$, weighed to $0.1 \mathrm{mg}$ ) of the respective PMMA powder was mixed with $10 \mathrm{~mL}$ acetonitrile. Subsequently, $1 \mathrm{~mL}$ of sample was mixed with $9 \mathrm{~mL}$ mobile phase, leading to the precipitation of the dissolved polymer. Each powder component was prepared three times.

\subsubsection{BPO content in cement moulds}

"Destructive" sample: An aliquot ( $\sim .5 \mathrm{~g}$, weighed to $0.1 \mathrm{mg})$ of the respective cement prepared as mentioned above was dissolved in $20 \mathrm{~mL}$ acetone over a period of $2 \mathrm{~h}$. 'Physiological Condition' sample: One cement mould ( $\sim 0.5 \mathrm{~g}$, weighed to $0.1 \mathrm{mg})$ of the 
respective cement was added to $5 \mathrm{~mL} \mathrm{NaCl}(0.9 \% \mathrm{~m} / \mathrm{m})$ solution and mixed for $30 \mathrm{~min}$. 'Non-physiological Condition' sample: One cement mould was added to $5 \mathrm{~mL}$ mobile phase and mixed for $30 \mathrm{~min}$.

\subsubsection{BP and BPO concentration in dissolved cement moulds}

To determine the BP and BPO concentration under non physiological conditions is in cement moulds of the selected brands, $\sim 0.5 \mathrm{~g}$ of each mould was dissolved in acetone for $2 \mathrm{~h}$ and analysed.

\subsubsection{BA, BP and BPO concentrations in $\mathrm{NaCl}$ extracts}

To mimic physiological conditions, cement moulds were incubated for 30 min in $5 \mathrm{~mL}$ $\mathrm{NaCl}$.

The limit of quantification was $1 \mu \mathrm{g} \mathrm{BPO} / \mathrm{g}$ cement.

\subsubsection{BA, BP and BPO concentrations in mobile phase extracts}

To determine $\mathrm{BPO}+(\mathrm{BPO}$ and degradation products) release under non- physiological conditions, cement moulds were mixed with $5 \mathrm{~mL}$ mobile phase (MP) and incubated for 30 min. Subsequently, the extract was analysed by HPLC (Stea et al., 1997).

\subsubsection{BA, BP and BPO concentrations in mobile phase extract after $24 \mathrm{~h}$}

Cement moulds were mixed with $5 \mathrm{~mL}$ mobile phase (MP) and incubated for $24 \mathrm{~h}$.

\section{Results}

The developed HPLC method with UV detection allowed the quantification of BA, BP and $\mathrm{BPO}$ in the polymer powder and the $\mathrm{NaCl}$ extracts. Furthermore, the quantification of BP and BPO was possible in the dissolved cement moulds as well as in the Mobile Phase (MP) extracts. Unfortunately, the BA quantification in cement moulds and MP were not possible as either the solvent (acetone) or other soluble cement constituents (colouring agents, antibiotics, etc.) interfered with the detection. The results were evaluated with the recoveries obtained from the spiking experiments of the determined compounds in the different experiments and provide reasonable statistical certainty.

\subsection{BPO content in the powder of selected cements}

The detected BPO content was lowest in $\mathrm{Copal}^{\circledR} \mathrm{G}+\mathrm{V}(6 \pm 0.3 \mathrm{mg} / \mathrm{g})$ and PALACOS ${ }^{\circledR}$ R $\quad(7 \pm 0.4 \mathrm{mg} / \mathrm{g})$. Antibiotic Simplex ${ }^{\circledR}$ T $(12 \pm 0.2 \mathrm{mg} / \mathrm{g}), \quad$ Cemex $^{\circledR}$ Genta $(14 \pm 0.4 \mathrm{mg} / \mathrm{g})$ and Hi Fatigue ${ }^{\circledR}(16 \pm 2 \mathrm{mg} / \mathrm{g})$ contained approximately twice as much. The highest BPO content was detected in $\mathrm{CMW}^{\circledR} 1 \mathrm{G}(20 \pm 0.4 \mathrm{mg} / \mathrm{g})$ (Figure 1). 
Figure 1 Measured concentrations of BA, BP and BPO in selected cement powders (see online version for colours)

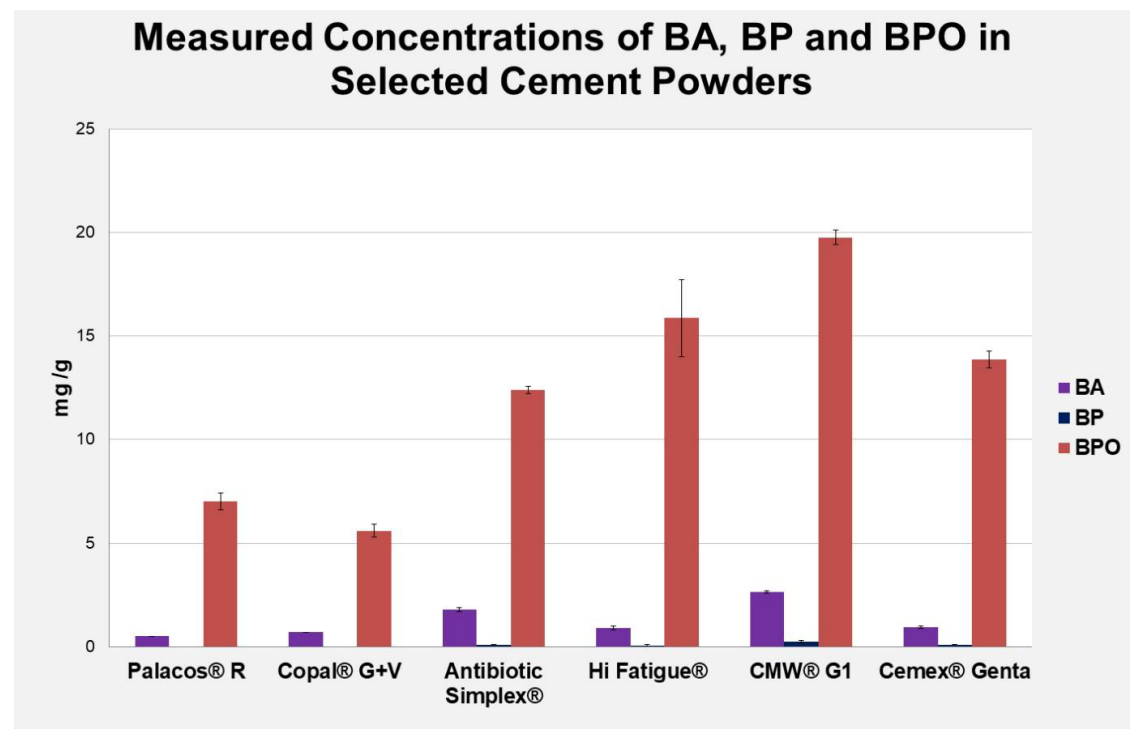

BP was absent in PALACOS ${ }^{\circledR} \mathrm{R}(<0.05 \mathrm{mg} / \mathrm{g})$ and $\mathrm{Copal}^{\circledR} \mathrm{G}+\mathrm{V}(<0.05 \mathrm{mg} / \mathrm{g})$, while traces were detectable in all other cements. The lowest concentration was detected in $\mathrm{Hi}$ Fatigue $^{\circledR}(0.1 \pm 0.06 \mathrm{mg} / \mathrm{g})$ followed by Antibiotic Simplex ${ }^{\circledR} \mathrm{T}$ and Cemex ${ }^{\circledR}$ Genta with $0.1 \pm 0.05 \mathrm{mg} / \mathrm{g}$ each, and $\mathrm{CMW}^{\circledR} 1 \mathrm{G}(0.2 \pm 0.06 \mathrm{mg} / \mathrm{g})$. (Figure 2).

Figure 2 BPO concentration in powder of selected cements (see online version for colours)

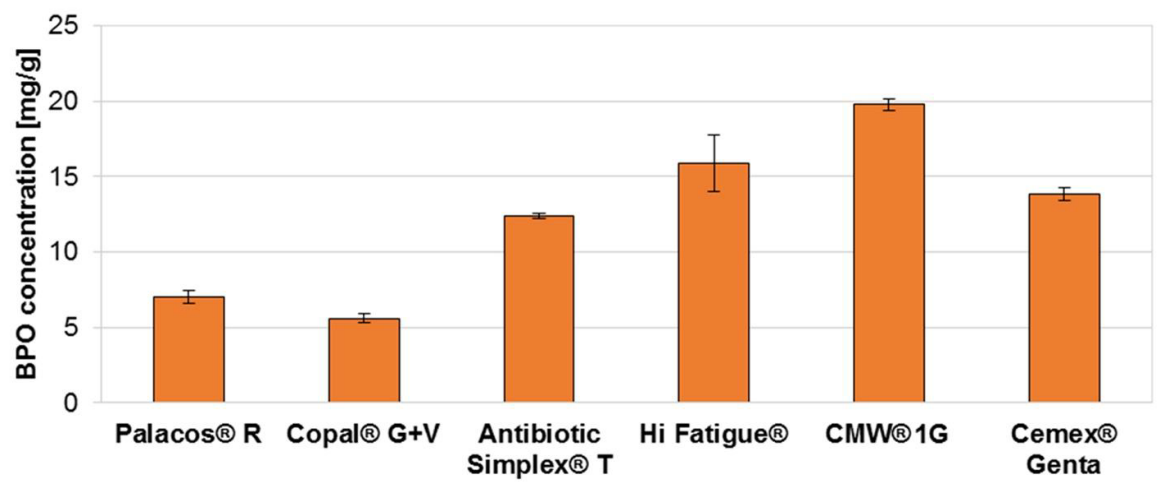

In 4 cases PALACOS ${ }^{\circledR} \mathrm{R}(7.5 \pm 0.4 \mathrm{mg} / \mathrm{g}), \mathrm{Copal}^{\circledR} \mathrm{G}+\mathrm{V}(6 \pm 0.3 \mathrm{mg} / \mathrm{g})$, Antibiotic Simplex ${ }^{\circledR} \mathrm{T}(14 \pm 0.1 \mathrm{mg} / \mathrm{g}), \mathrm{CMW}^{\circledR} 1 \mathrm{G}(23 \pm 0.4 \mathrm{mg} / \mathrm{g})$, the concentration measured in the cement powder was the same or close to the manufacturer's indications. The calculated BPO + concentration of the powder provided by Hi Fatigue ${ }^{\circledR}(17 \pm 2 \mathrm{mg} / \mathrm{g})$ was twice as high as expected concentration of $8.4 \mathrm{mg} / \mathrm{g}$. The other outlier was Cemex ${ }^{\circledR}$ Genta, which contained only half the amount $(15 \pm 1 \mathrm{mg} / \mathrm{g})$ of the expected BPO + concentration of $30 \mathrm{mg} / \mathrm{g}$ (Figure 3). 
Figure 3 Relative distribution of determined $\mathrm{BPO}+$ concentration in comparison to the manufacturer's indications $n=3$ (see online version for colours)

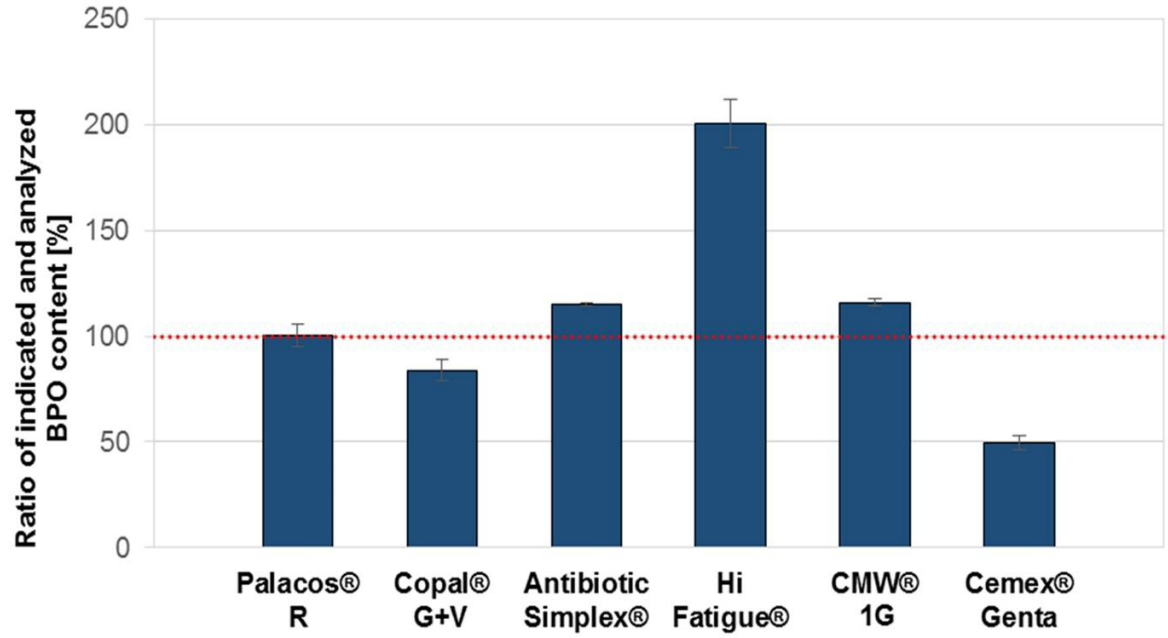

\subsection{BP and BPO concentration in dissolved moulds}

In general, the BP concentration was low in all samples analysed (Figure 4). In case of BPO, the concentration was low in PALACOS $^{\circledR} \mathrm{R}(500 \pm 220 \mu \mathrm{g} / \mathrm{g})$ and $\mathrm{Copal}^{\circledR} \mathrm{G}+\mathrm{V}$ $(\sim 470 \mu \mathrm{g} / \mathrm{g})$ again. In all other samples, it was at least 14 -fould higher with $\sim \mu \mathrm{g} / \mathrm{g}$ detected in Antibiotic Simplex ${ }^{\circledR}$ T, $7100 \pm 700 \mu \mathrm{g} / \mathrm{g}$ in Hi Fatigue ${ }^{\circledR}$ and $8800 \mu \mathrm{g} / \mathrm{g}$ in Cemex ${ }^{\circledR}$ Genta. The highest concentration was detected in the $\mathrm{CMW}^{\circledR} 1 \mathrm{G}$ sample, with $\sim 14000 \mu \mathrm{g} / \mathrm{g}$ (Figure 5).

Figure 4 BP concentration in acetone dissolved cement $(0,5 \mathrm{~g}$ cement dissolved in $20 \mathrm{~mL}$ acetone; subjected to HPLC UV analysis after $2 \mathrm{~h}$ ). Palacoa ${ }^{\circledR} \mathrm{R}$ and Hi fatigue ${ }^{\circledR} n=3$, other cements $n=1$ (see online version for colours)

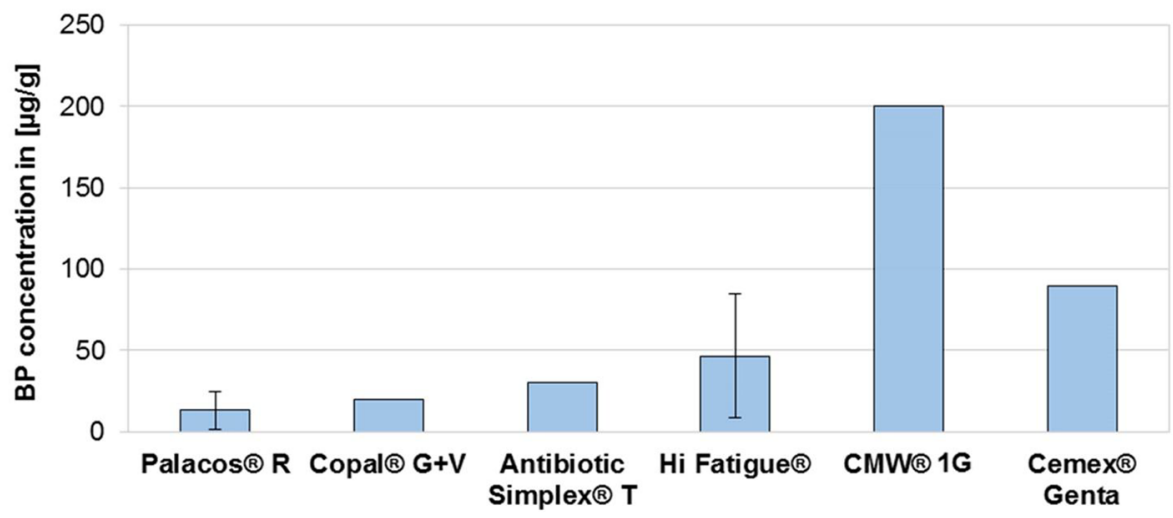


Figure 5 BPO concentrations in acetone dissolved cement $(0.5 \mathrm{~g}$ cement dissolved in $20 \mathrm{~mL}$ acetone; subjected to HPLC UV analysis after 2 h). Palacos ${ }^{\circledR} \mathrm{R}$ and Hi fatigue ${ }^{\circledR} n=3$, other cements $n=1$ (see online version for colours)

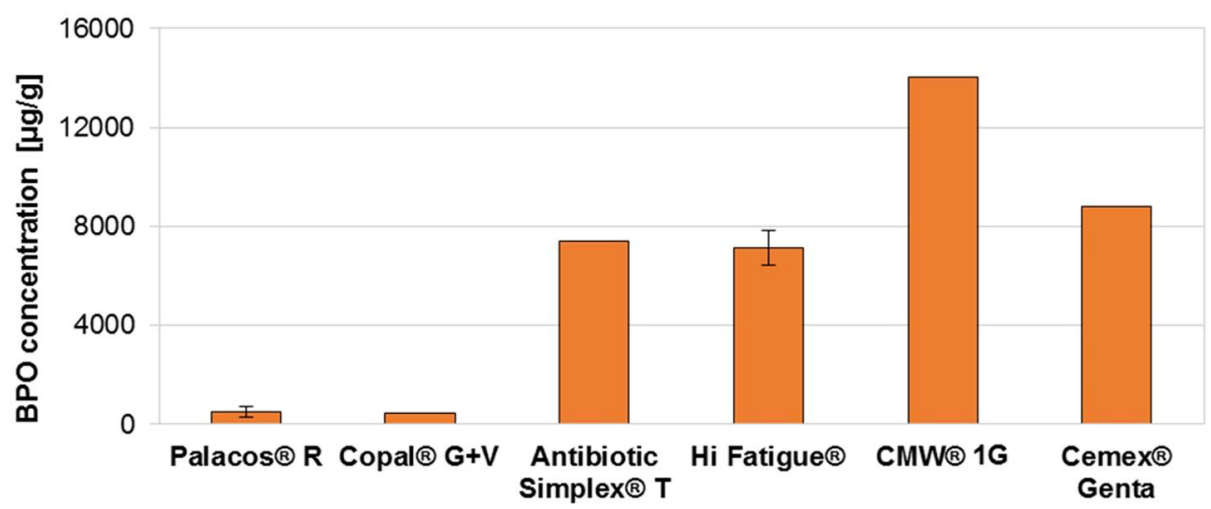

\subsection{BA, BP and BPO concentrations in $\mathrm{NaCl}$ extracts}

In all samples, a low amount of BA was detectable (Figure 6). BP and BPO were not detectable in any sample analysed.

\subsection{BA, BP and BPO concentrations in mobile phase extract after $24 \mathrm{~h}$}

In case of BPO, the MP extract of the PALACOS ${ }^{\circledR} \mathrm{R}$ and the Copal ${ }^{\circledR} \mathrm{G}+\mathrm{V}$ sample showed exceptionally low concentrations with $23 \pm 8 \mu \mathrm{g} / \mathrm{g}$ and $8 \mu \mathrm{g} / \mathrm{g}$, respectively. However, concentrations detected in the Antibiotic Simplex ${ }^{\circledR} \mathrm{T}$ sample $(\sim 509 \mu \mathrm{g} / \mathrm{g}), \mathrm{Hi}$ Fatigue $^{\circledR}(707 \pm 57 \mu \mathrm{g} / \mathrm{g})$ and Cemex ${ }^{\circledR}$ Genta $(\sim 786 \mu \mathrm{g} / \mathrm{g})$ where much higher, with a maximum concentration of $\sim 1100 \mu \mathrm{g} / \mathrm{g}$ in $\mathrm{CMW}^{\circledR} 1 \mathrm{G}$ (Figure 7).

Figure 6 BA concentrations in $\mathrm{NaCl}$ extract $(0.5 \mathrm{~g}$ cement in $5 \mathrm{~mL} \mathrm{naCl}$; subjected to HPLC $\mathrm{UV}$ analysis after $30 \mathrm{~min}$ ). Palacos ${ }^{\mathbb{R}} \mathrm{R}$ and Hi fatigue ${ }^{\mathbb{R}} n=3$, other cements $n=1$ (see online version for colours)

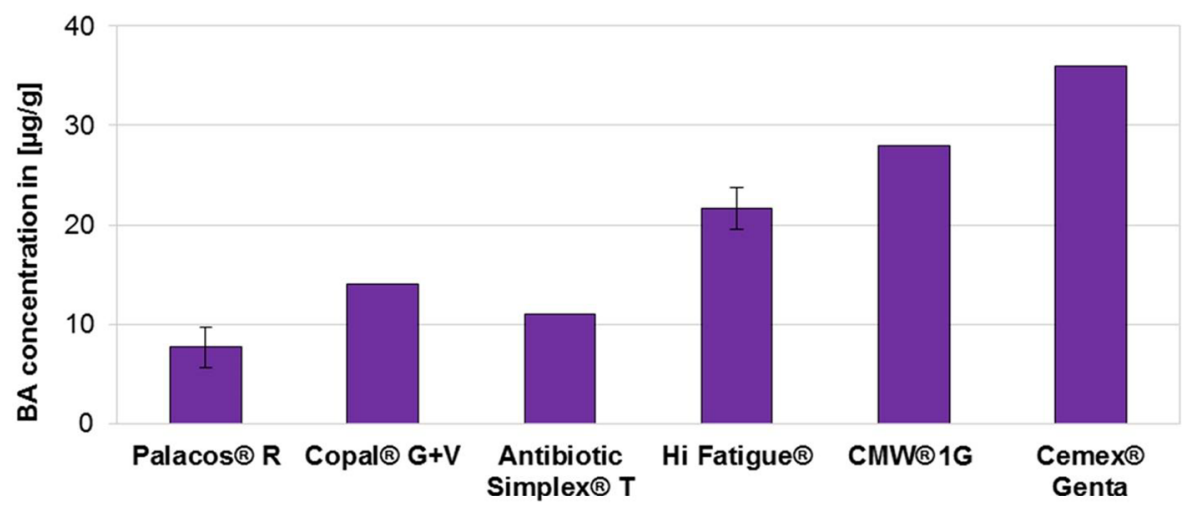


Figure 7 BPO concentrations in MP extract after 30 min. Palacos ${ }^{\circledR} \mathrm{R}$ and Hi fatigue ${ }^{\circledR} n=3$, other cements $n=1$ (see online version for colours)

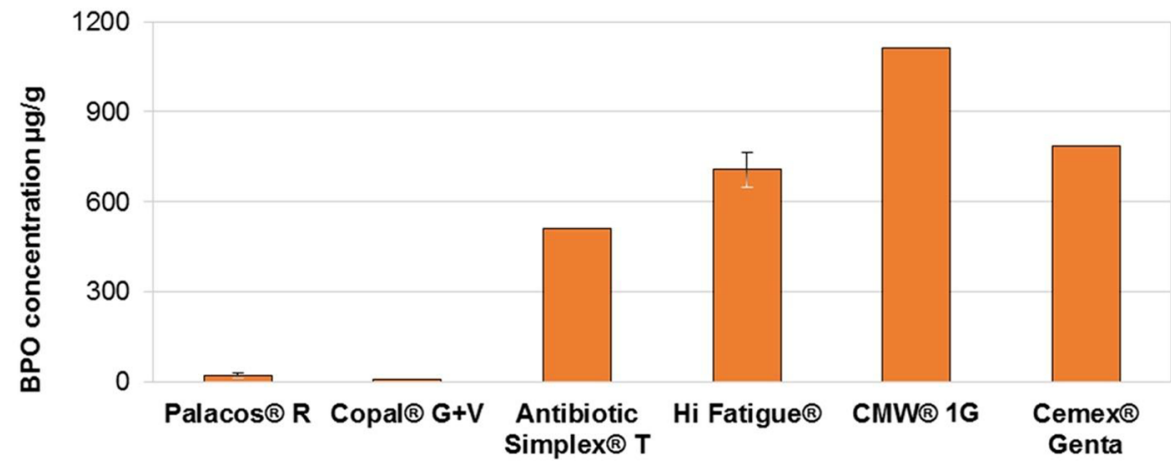

\subsection{BA, BP and BPO concentrations in mobile phase extracts}

The DmpT surplus in Palacos ${ }^{\circledR} \mathrm{R}$ did not allow the calculation of recovery of BPO.

In case of BPO, nothing could be detected in extracts of Palacos ${ }^{\circledR} \mathrm{R}$ and Antibiotic Simplex ${ }^{\circledR} \mathrm{T}(<1 \mu \mathrm{g} / \mathrm{g}$ cement $)$. In addition, the concentration was extremely low in Copal ${ }^{\circledR} \mathrm{G}+\mathrm{V}(\sim 3 \mu \mathrm{g} / \mathrm{g})$. However, high concentrations were found in extracts of Cemex $^{\circledR}$ Genta $(\sim 213 \mu \mathrm{g} / \mathrm{g})$, Hi Fatigue ${ }^{\circledR}(\sim 703 \mu \mathrm{g} / \mathrm{g}$ and $689 \mu \mathrm{g} / \mathrm{g})$ and $\mathrm{CMW}^{\circledR} 1 \mathrm{G}$ $(\sim 1380 \mu \mathrm{g} / \mathrm{g})$ (Figure 8$)$. This shows clearly the influence of the DmpT surplus as all samples from group 1 show a decrease of the BPO content, whereas the cements of group 2 show constant BPO concentrations (Figure 9).

Compared to the measured $\mathrm{BPO}+$ content in the powder component of the different brands, most BPO + was detected after destroying the cement. Destructing the hardened cement mould by dissolving it in acetone. This represents the maximum present BPO after polymerisation. Palacos ${ }^{\circledR} \mathrm{R}$ and $\mathrm{Copal}^{\circledR} \mathrm{G}+\mathrm{V}$ showed very low concentrations of $\mathrm{BPO}+$ (without BA) compared to the other cements. The BPO + content (actually only $\mathrm{BA}, \mathrm{BP}$ and $\mathrm{BPO}$ where not present) after 30 min incubation in $\mathrm{NaCl}$ was very low for all cements $(8-36 \mu \mathrm{g} / \mathrm{g})$ and very similar when compared to the initial BPO content $(\sim 0.1-0.3 \%)$, however slightly increased concentrations could be found in group 2 with BPO surplus.

Figure 8 BPO concentration in MP extracts after $24 \mathrm{~h}$. Palacos ${ }^{\circledR}$ and Hi fatigue ${ }^{\circledR} n=2$, other cements $n=1$ (see online version for colours)

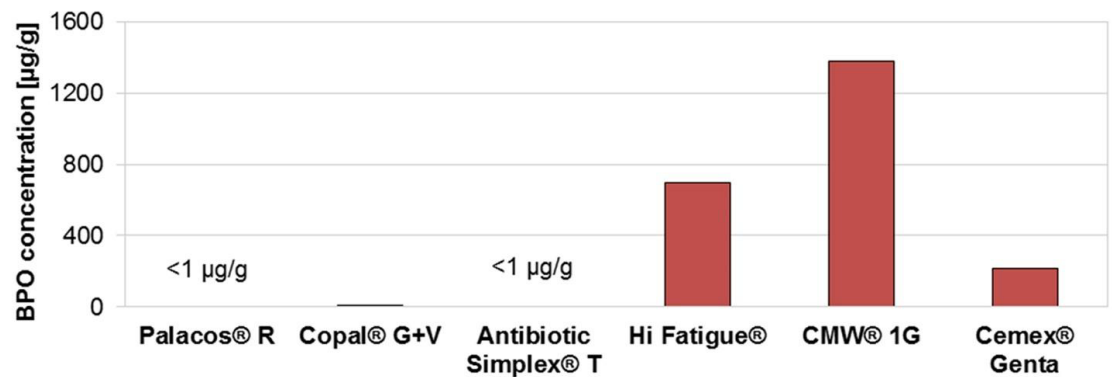


Figure 9 BPO concentrations in MP extracts after $24 \mathrm{~h}$. Palacos ${ }^{\circledR} \mathrm{R}$ and Hi fatigue ${ }^{\circledR} n=2$, other cements $n=1$ (see online version for colours)

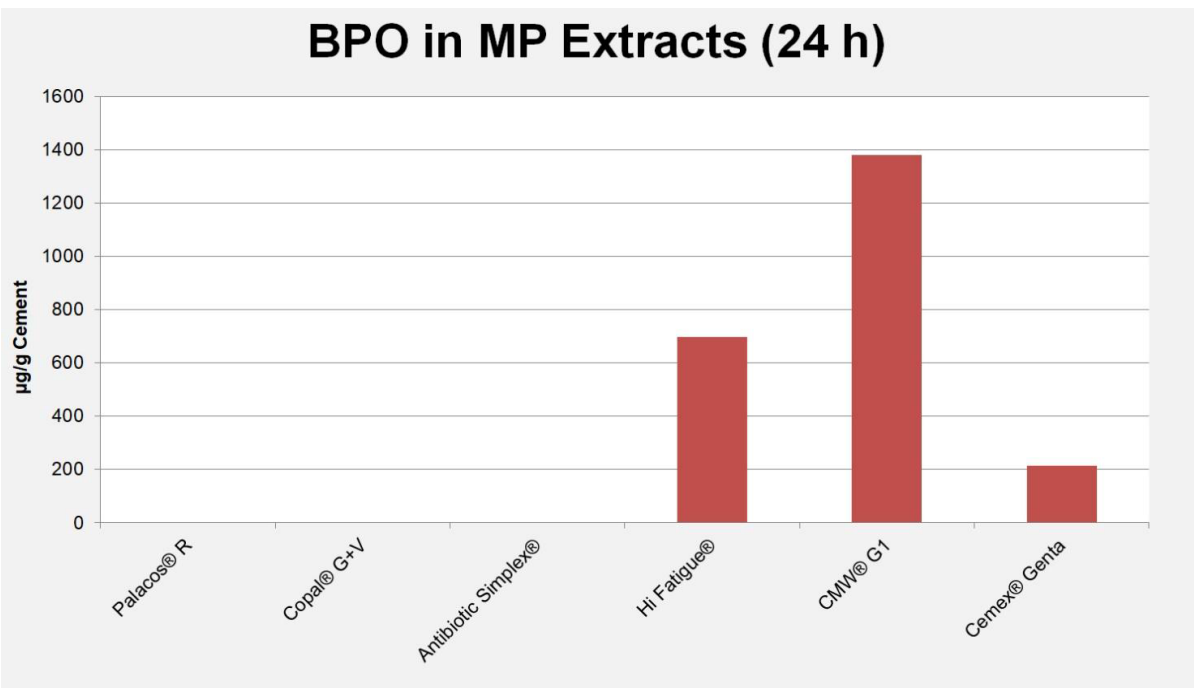

The 'Non-physiological Condition' samples show a significantly higher BPO + content in all cements, proofing the worst-case scenario. The BPO content in Palacos ${ }^{\circledR} \mathrm{R}$ and Copal $^{\circledR} \mathrm{G}+\mathrm{V}$ is very low though. The group 2 cements show higher BPO contents already after $30 \mathrm{~min}$ incubation and furthermore show still high concentrations of BPO after $24 \mathrm{~h}$ whereas the cements of group 1 with DmpT surplus show no remaining $\mathrm{BPO}$ anymore (BPO + content dominated by BP). However, the amount of BPO + varied between the cements under different conditions due to the difference of the input values. In cemented total joint arthroplasty, obviously more than $1 \mathrm{~g}$ cement is needed, and we estimated the total BPO concentration that could potentially be eluted from $40 \mathrm{~g}$ cement moulds under 'worst-case' conditions. The total BPO or BPO + content proportionally increases to the amount of utilised cement. Under non-physiological conditions after $30 \mathrm{~min}$ incubation in MP, which will not occur in the human body. the data clearly demonstrates that BPO elution is extremely low in case of Palacos ${ }^{\circledR} \mathrm{R}$ $(\sim 1 \mathrm{mg} / 40 \mathrm{~g})$ and Copal ${ }^{\circledR} \mathrm{G}+\mathrm{V}(\sim 0.4 \mathrm{mg} / 40 \mathrm{~g})$ compared to all other cements investigated (Antibiotic Simplex ${ }^{\circledR}$ T: $\sim 21 \mathrm{mg} / 40 \mathrm{~g}$; Hi Fatigue ${ }^{\circledR}$ : $\sim 28 \mathrm{mg} / 40 \mathrm{~g} ; \mathrm{GMW}^{\circledR}$ G1: $45 \mathrm{mg}$ / $40 \mathrm{~g}$; Cemex ${ }^{\circledR}$ Genta: $32 \mathrm{mg} / 40 \mathrm{~g}$ ) and even under harsh conditions (Table 2).

\section{Discussion}

HPLC analysed the components of six selected cements characterised by different BPO:DmpT ratio (Palacos ${ }^{\circledR} \mathrm{R}$, Copal ${ }^{\circledR} \mathrm{G}+\mathrm{V}$, Antibiotic Simplex ${ }^{\circledR} \mathrm{T}$, Hi Fatigue ${ }^{\circledR}$, $\mathrm{CMW}^{\circledR} 1 \mathrm{G}$ a n d Cemex ${ }^{\circledR}$ Genta). BPO and small amounts of its degradation products $\mathrm{BA}$ and BP were detected. This raises the question how these degradation products interact with DmpT and if they potentially impact on the cement quality. 
Table 2 Overview of the BPO + Content measured in the polymer powder and all compounded cements in $\mu \mathrm{g} / \mathrm{g}$ and in percent [\%] of the starting $\mathrm{BPO}+$ content in the powder considering the mixing ratio of powder and liquid cement components (indicated in brackets) (see online version for colours)

\begin{tabular}{|c|c|c|c|c|c|}
\hline Cement brand & $\begin{array}{l}\text { Powder } \\
\text { component }\end{array}$ & $\begin{array}{l}\text { Hardened } \\
\text { cement } \\
\text { dissolved in } \\
\text { acetone }\end{array}$ & $\begin{array}{l}\text { Hardened } \\
\text { cement } \\
\text { after } 30 \mathrm{~min} \\
\text { in } \mathrm{NaCl}\end{array}$ & $\begin{array}{c}\text { Hardened } \\
\text { cement } \\
\text { after } 30 \text { min } \\
\text { MP }\end{array}$ & $\begin{array}{c}\text { Hardened } \\
\text { cement } \\
\text { after } 24 h\end{array}$ \\
\hline 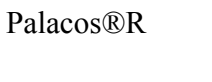 & $7500(100 \%)$ & $500(10 \%)$ & $8(0.2 \%)$ & $24(0.5 \%)$ & $\begin{array}{c}<1 \\
(<0.02 \%)\end{array}$ \\
\hline Copal ${ }^{\circledR} \mathrm{G}+\mathrm{V}$ & $6300(100 \%)$ & $490(11 \%)$ & $14(0.3 \%)$ & $9(0.2 \%)$ & $8(0.2 \%)$ \\
\hline $\begin{array}{l}\text { Antibiotic } \\
\text { Simplex }{ }^{\circledR T}\end{array}$ & $14300(100 \%)$ & $7430(76 \%)$ & $11(0.1 \%)$ & $518(5 \%)$ & $16(0.2 \%)$ \\
\hline Hi Fatigue ${ }^{\circledR}$ & $16800(100 \%)$ & $7180(63 \%)$ & $21(0.2 \%)$ & $709(6 \%)$ & $696 *(6 \%)$ \\
\hline $\mathrm{CMW}{ }^{\circledR} 1 \mathrm{G}$ & $22600(100 \%)$ & $14200(92 \%)$ & $28(0.2 \%)$ & $1122(7 \%)$ & $1413(9 \%)$ \\
\hline Cemex ${ }^{\circledR}$ Genta & $14900(100 \%)$ & $8890(81 \%)$ & $36(0.2 \%)$ & $796(7 \%)$ & $230(2 \%)$ \\
\hline
\end{tabular}

*Average of two individual measurements.

Comparing the measured $\mathrm{BPO}+$ concentrations revealed same or close values as given by the manufacturers in four cases $\left(\right.$ Palacos $^{\circledR} \mathrm{R}, \mathrm{Copal}^{\circledR} \mathrm{G}+\mathrm{V}$, Antibiotic Simplex ${ }^{\circledR}$, $\left.\mathrm{CMW}^{\circledR} 1 \mathrm{G}\right)$. However, BPO + concentration calculated for Hi Fatigue ${ }^{\circledR}$ was twice as high as expected $(8.4: 17 \pm 2 \mathrm{mg} / \mathrm{g})$, while $\mathrm{Cemex}^{\circledR}$ Genta contained only half the amount of the expected $\mathrm{BPO}+(30: 15 \pm 0.5 \mathrm{mg} / \mathrm{g})$. Discrepancies between the values given by the manufacturers on the package and measured BPO content was already reported by Imai and Ohyama (2001). Remarkable is the good coincidence between measured concentrations and manufacturer declaration for products being established on the marked for a long time. Unlike Palacos ${ }^{\circledR} \mathrm{R}, \mathrm{Copal}^{\circledR} \mathrm{G}+\mathrm{V}$, Antibiotic Simplex ${ }^{\circledR} \mathrm{T}$ and $\mathrm{CMW}^{\circledR}$ $1 \mathrm{G}$, Hi Fatigue ${ }^{\circledR}$ and Cemex $^{\circledR}$ Genta were established later and under different legal regulations. Initially, all bone cement contents were defined as active substances by the pharmaceutical law. Thus, precise indication was obligate. However, nowadays and according to the Medical Device Guidelines, the manufacturer is not obligated to disclose the precise composition of the PMMA cement compounds (AMG, 2004), ASTM Specification F 451-476 (1978) and Kühn (2000). Consequently, the disclosures should rather be considered as being an indicative value that may vary between batches. Thus, precise content disclosures would be desirable, and manufacturers with extremely deviating values should reconsider their indications. To analyse the BPO and $\mathrm{BP}$ content in the hardened cement, moulds were prepared and dissolved in acetone.

A limitation of the experimental setting was that the analysis of BA was not possible, because acetone overlapped with the BA in HPLC chromatograms. As can be expected from the BPO/DmpT ratio, high BPO/BP concentrations were detected in Hi Fatigue ${ }^{\circledR}$, $\mathrm{CMW}^{\circledR} 1 \mathrm{G}$ and Cemex ${ }^{\circledR}$ Genta, thus all cements that contained an initial BPO surplus compared to DmpT. A low BPO/BP concentration was detected only in Palacos ${ }^{\circledR} \mathrm{R}$ and Copal $^{\circledR} \mathrm{G}+\mathrm{V}$, both cements with DmpT surplus compared to BPO. Indeed, a DmpT surplus seems to favour an increased consumption of BPO. However, Antibiotic 
Simplex ${ }^{\circledR}$ with Tobramycin revealed high concentrations of BPO as well, although classified as Group 2 DmpT surplus cement. The reason may be that the ratio of BPO vs. DmpT is lower in Antibiotic Simplex ${ }^{\circledR} \mathrm{T}(1: 1.8) \operatorname{compared~to~Palacos~}^{\circledR} \mathrm{R}$ and $\mathrm{Copal}^{\circledR} \mathrm{G}+\mathrm{V}$ (1:2.4 each). The lower amount of DmpT might be crucial and could be responsible for the decreased consumption of BPO. The experiment merely evidences that $\mathrm{BPO}$ and degradation products $(\mathrm{BPO}+)$ remains in higher concentrations in the hardened cement if an initial BPO surplus exists.

To mimic physiological conditions, cement moulds were incubated in $\mathrm{NaCl}$ for $30 \mathrm{~min}$. The above described findings demonstrate that only traces of BPO + are eluted under physiological conditions. In contrast to the low solubility of BPO under physiological conditions, BA is indeed soluble. Of course, this approach cannot be used to make an assessment about the BPO + release of cements in the human body. However, the experiment shows that the risk of BPO + release under physiological conditions is rather low, at least in the short term. It remains to be determined whether firstly ex vivo retrieved bone cement samples might still contain BPO and secondly abrasive bone cement wear/particle generation gives an additional possibility of BPO release. To investigate if $\mathrm{BPO}+$ can be eluted at all from hardened cements without their destruction, cement moulds were incubated in MP for 0.5 and $24 \mathrm{~h}$ and extracts were analysed. Cements were bloated after the treatment. Cements of Group 2 with DmpT surplus revealed lower BP values after 0.5 and $24 \mathrm{~h}$. Again, the values were lower for Palacos ${ }^{\circledR} \mathrm{R}$ and Copal $^{\circledR} \mathrm{G}+\mathrm{V}$ compared to Hi Fatigue ${ }^{\circledR}$. Nevertheless, detected BP values in all samples of Group 2 were much lower compared to Group 1. The same results were achieved after analysis of BPO, apart from Hi Fatigue ${ }^{\circledR}$ sample that contained similar BPO concentrations as Group 1 cements after $0.5 \mathrm{~h}$. These results repeatedly show that a DmpT surplus favours increased consumption of BPO.

Thus, under non-physiological conditions it is in principle possible to elute BPO + from cement moulds. However, these conditions would not occur in the human body and the above described concentrations of $\mathrm{BPO}+$ will not be eluted under physiological conditions.

In conclusion, hardened cements of group 1 with DmpT surplus contained less BPO + compared to group 2 with BPO surplus under all tested conditions. Furthermore, the ratio of DmpT:PBO had an impact on the turnover of BPO. In all cases, BPO and BP elution under physiological conditions was not detectable, calling into question whether BPO is relevant as PMMA cement allergen. Especially, since BPO is rapidly metabolised in the body (Treudler and Simon, 2007). Indeed, Thomas et al. (2013) found that patch testing performed in arthroplasty patients with complaints revealed a BPO contact allergy in $8 \%$ of cases. However, testing in symptom free arthroplasty patients revealed a BPO contact allergy in $6.7 \%$ of cases, raising further doubts of BPO being the main cause of the complaints. This observation may indicate that respective patients were sensitised during the period of cementing when exposed to BPO. However, there are few reported cases like those described by Bircher et al. (2012) with potential relevant BPO allergy. Furthermore, the Deutsche Kontaktallergie- Gruppe (DKG) [German Contact Allergy group] has issued that patch testing with BPO-preparation has a high risk of irritative reactions and thus results may be misinterpreted by non-experienced examiner as 'false' positive results, as well (Geier et al., 2008). However, despite such pitfalls in allergology diagnostics, we recommend allergen testing in complicated cemented orthopaedic implants. The opposite example is gentamicin-allergy in cemented arthroplasty, since 
i such allergy can be clearly detected by patch test

ii there is in fact prolonged release of gentamicin from bone cement (Thomas, 2015).

Based on our findings, we recommend a cement with DmpT surplus in case of positive BPO allergy, unless cementless total joint arthroplasty is not possible. A limitation of this study is that only BPO has been investigated. It would be interesting to analyse the DmpT values of the same cements under the same conditions, to compare the outcome with the present data. An additional future approach would be analysis of 'ex-vivo' bone cement samples obtained during revision surgery.

\section{Conflict of interest}

All authors declare that they have no conflict of interest.

\section{References}

AMG (2004) German Drug Act, [Law on the Marketing of Drugs as amended by the Notice] Gesetz über den Verkehr mit Arzneimitteln in der Fassung der Bekanntmachung vom 11.12.1998, BGBI. I. 3586, Zuletzt Geändert Am 09.12.2004, BGBI. I, 3214.

ASTM Specification, F 451-476 (1978) Standard Specification for Acrylic Bone Cement. Annual Book of ASTM Standards: Medical Devices; Emergency Medical Services. American Society for Testing and Materials, Philadelphia, PA, pp.451-476.

Bircher, A., Friederich, N.F., Seelig, W. and Scherer, K. (2012) 'Allergic complications from orthopaedic joint implants: the role of delayed hypersensitivity to benzoyl peroxide in bone cement', Contact Dermatitis, Vol. 66, No. 1, pp.20-26.

Carlsson, A.S., Magnusson, B. and Moller H: (1980) 'Metal sensitivity in patients with metal-toplastic total hip arthroplasties', Acta Orthop Scand., Vol. 51, No. 1, pp.57-62.

Deb, S. (2008) Orthopaedic Bone Cement, Woodhead Publishing 2008 eBook ISBN: 9781845695170, URL: https://www.elsevier.com/books/orthopaedic-bone-cements/deb/9781-84569-376-3 (Accessed 16 October, 2008).

Edwards, S.A. and Gardiner, J. (2007) 'Hypersensitivity to benzoyl peroxide in a cemented total knee arthroplasty: cement allergy', J. Arthroplasty, Vol. 22, No. 8, pp.1226-1228.

Ege, W. (1993) '[Bone cement] knochenzement', in Planck H. (Ed.): [Plastics and elastomers in medicine] kunststoffe und elastomere in der medizin, Kohlhammer gmbH. Stuttgart, Vol. 37, pp.293-302, ISBN: 978-3170096028.

Faschingbauer, M., Renner, L., and Boettner, F. (2017) 'Allergy in total knee replacement', Does It Exist? HSS Journal, Vol. 13, pp.12-19.

Gaddipati, N., Volpe, F. and Anthony, G. (1983) 'Quantitative determination of benzoyl peroxide by high-performance liquid chromatography and comparison to the iodometric method 1983', J. Pharm. Sci., Vol. 72, No. 12, pp.1398-1400.

Geier, J., Lessmann, H., Becker, D. and Thomas, P. (2008) 'Allergy diagnostics in suspected implant intolerance: practical approach', A Position Paper of the German Contact Dermatitis Research Group (DKG), Hautarzt., Vol. 59, No. 7, pp.594-559.

Goodman, S.B. (1996) 'Does the immune system play a role in loosening and osteolysis of total joint replacements?', J. Long Term Eff Med Implants, Vol. 6, No. 2, pp.91-101.

Gothner, M., Ozokyay, L., Godau, P., Kalicke, T., Muhr, G., Schildhauer, T.A. and Dudda, M. (2011) '[Association between allergy to benzoyl peroxide, vitiligo and implantation of a cemented total knee joint prosthesis: is there a connection?]', Orthopäde, Vol. 40, No. 9, pp.802-806. 
Haddad, F., Levell, N., Dowd, P., Cobb, A. and Bentley, G. (1995) 'Cement hypersensitivity: a cause of aseptic loosening?', J. Bone Joint Surg Br., Vol. 77, No. 2, pp.329-330.

Haddad, F.S., Cobb, A.G., Bentley, G., Levell, N.J. and Dowd, P.M. (1996) 'Hypersensitivity in aseptic loosening of total hip replacements. the role of constituents of bone cement', J. Bone Joint Surg Br., Vol. 78, No. 4, pp.546-549.

Hallab, N., Merritt, K. and Jacobs, J.J. (2001) 'Metal sensitivity in patients with orthopaedic implants', J. Bone Joint Surg Am., Vol. 83-A, No. 3, pp.428-436.

Imai, Y. and Ohyama, A. (2001) 'Characterization of powder components of commercial bone cements', Dent Mater. J., Vol. 20, No. 4, pp.345-352.

Jäger, M. and Balda, B.R. (1979) 'Loosening of a total hip prosthesis at contact allergy due to benzoyl peroxide', Arch Orthop Trauma Surg., Vol. 94, No. 3, pp.175-178.

Kruppke, B. (2010) [Antibiotic-Loaded Bone Cements, Balance between Active Substance Release, Processing and Mechanical Properties. Documentary Work in the Material Sciences Course, Material Science of the Technical University of Dresden 2010] Antibiotikahaltige Knochenzemente, Balance zwischen Wirkstofffreisetzung Verarbeitung und mechanischen eigenschaften. Belegarbeit im Studiengang Werkstoffwissenschaften, Studienrichtung Materialwissenschaft der TU Dresden.

Kubba, R., Taylor, J.S. and Marks, K.E. (1981) 'Cutaneous complications of orthopedic implants. A two-year prospective study', Arch Dermatol. 1, Vol. 117, No. 9, pp.554-560.

Kühn, K.D. (2000) Bone Cements. Up-to-Date Comparison of Physical and Chemical Properties of Commercial Materials, Springer, Berlin Heidelberg, ISBN: 978-3-642-59762-6.

Kühn, K.D. (2014) PMMA Cements, Springer, Berlin Heidelberg, ISBN: 978-3-642-41535-7.

Meel, B.L. (2004) 'Fatal systemic allergic reaction following acrylic cranioplasty: a case report', J. Clin. Forensic Med., Vol. 11, No. 4, pp.205-207.

Nussbaum, D., Gailloud, P. and Murphy, K. (2004) 'The chemistry of acrylic bone cements and implications for clinical use in image-guided therapy', JVIR, Vol. 15, No. 2, pp.121-126.

Pegum, J. and Medhurst, F. (1971) 'Contact dermatitis from penetration of rubber gloves by acrylic monomer', Br. Med. J., Vol. 2, No. 5754, 17 April, pp.141-143, doi: 10.1136/bmj.2.5754.141.

Richter-Hintz, D., Rieker, J., Rauch, L. and Homey, B. (2005) 'Sensitivity to constituents of bone cement in a patient with joint prosthesis', Hautarzt, Vol. 55, No. 10, pp.987-989.

Rodgers, K., Klykken, P., Jacobs, J., Frondoza, C., Tomazic, V. and Zelikoff, J. (1997) 'Immunotoxicity of medical devices', Symposium Overview. Fundam Appl Toxicol, Vol. 36, No. 1, pp.1-14.

Romaguera, C., Grimalt, F. and Vilaplana, J. (1985) 'Methyl methacrylate prosthesis dermatitis', Contact Dermatitis, Vol. 12, No. 3, pp.172-183.

Schuh, A., Thomas, P., Holzwarth, U. and Zeiler, G. (2004) '[Bilateral localized osteolysis after cemented total hip replacement]', Orthopäde, Vol. 33, No. 6, pp.727-732.

Schuh, A., Thomas, P., Reinhold, R., Holzwarth, U., Zeiler, G. and Mahler, V. (2006) '[Allergy to bone cement components after knee endoprosthesis implantation.]. allergie auf knochenzementbestandteile nach knieendoprothesenimplantation', Zentralblatt Für Chirurgie, Vol. 131, No. 05, pp.429-431.

Shintani, H., Tsuchiya, T., Hata, Y. and Nakamura, A. (1993) 'Solid phase extraction and HPLC analysis of toxic components eluted from methyl methacrylate dental materials', J. Anal Toxicol, Vol. 17, No. 2, pp.73-78.

Stea, S., Granchi, D., Zolezzi, C., Ciapetti, G., Visentin, M., Cavedagna, D. and Pizzo-ferrato, A. (1997) 'High-performance liquid chromatography assay of N, N-dimethyl-p-toluidine released from bone cements: evidence for toxicity', Biomaterials, Vol. 18, No. 3, pp.243-246.

Thomas, B., Kulichova, D., Wolf, R., Summer, B., Mahler, V. and Thomas, P. (2015) 'High frequency of contact allergy to implant and bone cement components', Particular Gentamicin. In Cemented Arthroplasty with Complications: Usefulness of Late Patch Test Reading, Contact Dermatitis, Vol. 73, No. 6, pp.343-3. 
Thomas, P. (2003) 'Allergic reactions to implant materials', Der Orthopäde, Vol. 32, No. 1, pp.60-64.

Thomas, P., Barnstorf, S., Rueff, F., Przybilla, B. and Summer, B. (2004) '[Contact allergy to endoprosthesis components as a possible cause of knee endoprosthesis intolerance] kontaktallergie gegen endoprothesenkomponenten als mögliche ursache einer knieendoprothesen-unverträglichkeit', Allergo J, Vol. 13, p.51.

Thomas, P., Schuh, A., Summer, B., Mazoochian, F. and Thomsen, M. (2006) '[Allergy towards bone cement]',. Der Orthopäde, Vol. 35, No. 9, pp.958-960.

Thomas, P., Stauner, K., Schraml, A., Mahler, V., Banke, I.J., Gollwitzer, H., Burgkart, R. and Prodinger, P.M., Schneider, S., Pritschet, M., Mazoochian, F., Schopf, C., Steinmann, A., Summer, B. (2013) '[Characteristics of 200 patients with suspected implant allergy compared to 100 symptom-free arthroplasty patients]', Orthopaede, Vol. 42, No. 8, pp.607-613.

Treudler, R. and Simon, J.C. (2007) 'Benzoyl peroxide: is it a relevant bone cement allergen in patients with orthopaedic implants?', Contact Dermatitis, Vol. 57, No. 3, pp.177-180.

Wawrzynski, J., Gil, J.A., Goodman, A. and Waryasz, G.R. (2017) 'Hypersensitivity to orthopedic implants: a review of literature', Rheumatol Ther., Vol. 4, No. 1, June, pp.45-56, doi: 10.1007/s40744-017-0062-6. Epub 31 March 2017.

Wetzel, S. and Thomas, P. (2004) 'Allergy to implant materials', in Plewig, G., Kaudewitz, P. and Sander, C.A. (Eds.): Advances in Practical Dermatology and Venerology, Fortschritte Der Praktischen Dermatologie Und Venerologie., Allergie gegen implantatwerkstoffe.

Willert, H.G., Buchhorn, G.H., Fayyazi, A., Flury, R., Windler, M., Köster, G. and Lohmann, C.H. (2005) 'Metal-on-metal bearings and hypersensitivity in patients with artificial hip joints. A clinical and histomorphological study', J. Bone Joint Surg Am., Vol. 87, No. 1, pp.28-36. 